\title{
PENGARUH KULTUR CAMPURAN DALAM FERMENTASI ALKOHOL TERHADAP SIFAT FISIKOKIMIA DAN SENSORIS CUKA BELIMBING WULUH (Averrhoa bilimbi L.)
}

\section{Effect of Mixed Cultures in Alcoholic Fermentation on the Physicochemical and Sensory Properties of Bilimbi Vinegar (Averrhoa bilimbi L.)}

\author{
Izzatul Laily ${ }^{1}$, Wesiana Heris Santy², Viera Nu'riza Pratiwi ${ }^{1 *}$ \\ ${ }^{1}$ Program Studi Gizi, Fakultas Kesehatan, Universitas Nahdlatul Ulama Surabaya \\ ${ }^{2}$ Program Studi Keperawatan, Fakultas Keperawatan dan Kebidanan, Universitas Nahdlatul \\ Ulama Surabaya \\ *Penulis Korespondensi, Email: vieranpratiwi@unusa.ac.id
}

\begin{abstract}
ABSTRAK
Belimbing wuluh (Averrhoa bilimbi L.) merupakan buah dengan manfaat kesehatan yang beragam. Pemanfaatan belimbing wuluh masih terbatas dan banyak terbuang. Penelitian ini memanfaatkan belimbing wuluh dalam pembuatan cuka. Proses pembuatan cuka dilakukan dengan dua tahapan yaitu fermentasi alkohol dan fermentasi asam asetat. Tujuan dari penelitian ini adalah menganalisis pengaruh fermentasi alkohol yang menggunakan kultur campuran (S. cerevisiae dan L. plantarum) terhadap cuka belimbing wuluh (sifat fisikokimia dan sensoris). L. plantarum dengan konsentrasi $1 \%, 2 \%, 4 \%$ digunakan pada fermentasi alkohol. Hasil dari pengujian diperoleh $\mathrm{pH}$ wine dan cuka adalah berkisar 3.57-3.65, kadar alkohol wine adalah 5.68-9.46\%, kadar asam asetat berkisar 0.32$0.35 \%$, aktivitas antioksidan 2.51 hingga $4.95 \mathrm{ppm}$, kadar fenolik berkisar 28.07 hingga $29.49 \mathrm{mg} \mathrm{GAE} / \mathrm{g}$. Hasil uji sensoris yang dilakukan didapatkan nilai yang hampir seragam antara cuka dengan penambahan $L$. plantarum konsentrasi berbeda.
\end{abstract}

Kata kunci : Belimbing Wuluh, Cuka, Kultur Campuran

\section{ABSTRACT}

Belimbing wuluh (Averrhoa bilimbi L.) is a fruit with many health benefits. The use of belimbing wuluh is still limited and wasted. This research utilizes belimbing wuluh in vinegar fermentation. The process of making vinegar is done in two stages namely alcoholic fermentation and acetic acid fermentation. The purpose of this study was to analyze the effect of alcohol fermentation using mixed cultures (S. cerevisiae and L. plantarum) on belimbing wuluh vinegar (physicochemical and sensory properties). L. plantarum with a concentration of $1 \%, 2 \%, 4 \%$ is used in alcoholic fermentation. The results showed that $\mathrm{pH}$ of wine and vinegar ranged from 3.57 to 3.65, alcohol content was 5.68-9.46\%, acetic acid levels ranged from 0.32 to $0.35 \%$, antioxidant activity was 2.51 to $4.95 \mathrm{ppm}$, and phenolic levels range from 28.07 to $29.49 \mathrm{mg} \mathrm{GAE} \mathrm{/} \mathrm{g.} \mathrm{Sensory} \mathrm{test} \mathrm{results} \mathrm{obtained} \mathrm{were} \mathrm{almost}$ same values between vinegar with the addition of different $L$. plantarum concentrations.

Keywords : Bilimbi, Mixed Culture, Vinegar

\section{PENDAHULUAN}

Cuka dikenal luas di seluruh dunia dan digunakan sebagai bahan penambah cita rasa masakan. Cuka juga berfungsi sebagai bahan pengawet alami dan dapat menjaga kualitas warna makanan tetap menarik. Selain berfungsi sebagai salah satu bahan masakan, ternyata cuka juga berpotensial memberikan manfaat kesehatan pada tubuh. Cuka diklaim memiliki sifat antimikroba, antioksidan, antidiabetes, antitumor, dan antihipertensi (Johnston 
\& Gaas, 2006; Budak et al, 2014). Banyaknya bukti ilmiah yang dilaporkan oleh peneliti membuat semakin banyak masyarakat yang berminat untuk mengonsumsi cuka.

Secara tradisional cuka terbuat dari bahan baku yang mengandung tepung atau gula. Cuka di Indonesia paling banyak terbuat dari nira aren kelapa. Seiring perkembangan teknologi, cuka juga diproduksi dari bahan lain termasuk ekstrak atau jus buah-buahan seperti anggur, apel, tomat, kelapa, dan plum. Beberapa peneliti juga mencoba membuat cuka berasal dari bahan lain seperti kurma (Hafzan dkk, 2017), kulit pisang (Ni'maturrohmah, 2014), dan bunga rosella (Firdausni, 2013). Terlepas dari penelitian sebelumnya terkait pemanfaatan bahan lain, terdapat bahan lokal yang belum banyak diketahui pemanfaatannya dan memiliki potensi sebagai bahan dasar pembuatan cuka diantaranya adalah buah belimbing wuluh.

Belimbing wuluh (Averrhoa bilimbi L.) merupakan tanaman yang menghasilkan kurang lebih 100-300 buah dalam satu pohon (Soetanto, 1998 dalam Oktaviana, 2012). Jumlah buah yang dihasilkan tersebut tidak sebanding dengan pengolahan belimbing wuluh oleh masyarakat, sehingga lebih banyak terbuang. Belimbing wuluh yang telah matang banyak terbuang dan membusuk karena mudah gugur dari pohonnya. Belimbing wuluh memiliki banyak senyawa antioksidan seperti flavonoid, saponin, kumarin dan zat lain yaitu pektin dan minyak atsiri (Harmanto, 2001; Masruhen, 2010).

Pembuatan cuka melibatkan dua proses biokimia : fermentasi alkohol yaitu proses konversi gula menjadi etanol yang bersifat anaerobik oleh ragi (biasanya Saccharomyces); dan fermentasi asam asetat yaitu oksidasi dari senyawa etanol menjadi asam asetat yang bersifat aerobik oleh bakteri, biasanya Acetobacter (Chen et al., 2017). Proses fermentasi alkohol umumnya dilakukan menggunakan kultur tunggal yaitu ragi. Berbeda dengan proses fermentasi cuka pada umumnya, proses fermentasi cuka yang dilakukan secara tradisional di China melibatkan kultur campuran seperti Aspergillus niger, S. cerevisiae, dan Lactobacillus. Cuka yang dihasilkan melalui proses fermentasi dengan menggunakan kultur tunggal dan kultur campuran memiliki flavor yang berbeda. Cuka dengan kultur campuran memiliki flavor yang lebih baik (Liu et al., 2004).

Penelitian oleh Wang et al. (2013) menunjukkan penggunaan kultur campuran $S$. cerevisiae dan $A$. pasteurianus dapat meningkatkan kadar asam asetat dalam cuka dan memperpendek waktu fermentasi. Penelitian sebelumnya oleh Chen et al. (2017), telah dilakukan studi awal untuk mengetahui perbedaan sifat fisikokimia dan sensoris cuka jeruk yang dihasilkan melalui fermentasi alkohol menggunakan kultur tunggal dan kultur campuran $S$. cerevisiae dan L. plantarum. Tujuan dari penelitian ini adalah untuk menganalisis pengaruh fermentasi alkohol yang menggunakan kultur campuran ( $S$. cerevisiae dan $L$. plantarum) terhadap cuka belimbing wuluh (sifat fisikokimia dan sensoris).

\section{BAHAN DAN METODE}

\section{Bahan}

Bahan yang digunakan adalah buah belimbing wuluh yang berasal dari wilayah Surabaya, air mineral, gula pasir, natrium karbonat, Saccharomyces cerevisiae, Lactobacillus plantarum AS1.555, Acetobacter acetii, yeast extract, glucose, peptone, MRSB. Bahan untuk analisis sifat fisikokimia antara lain akuades, indikator PP (Phenol Phtalein), $\mathrm{NaOH} 0.1 \mathrm{~N}$, reagen $\mathrm{DPPH}$, asam askorbat, methanol, gallic acid, Folinciocalteau, dan $\mathrm{Na}_{2} \mathrm{CO}_{3}$.

\section{Alat}

Alat dalam pembuatan cuka belimbing wuluh adalah timbangan digital, baskom, pisau, blender (Philips HR2115/00), kain saring, gelas ukur plastik, gelas beker, corong, kertas saring whattman, pengaduk, gelas ukur, botol UC, jarum ose, bunsen, autoklaf, inkubator (Memmert IN55), refraktometer, alat sentrifugasi, hot plate. Alat untuk analisis sifat fisikokimia adalah neraca analitik (OHAUS CP214), pHmeter (Trans Instruments pH/MVDRP/Temp Meter HP 9000), labu suling, piknometer, labu erlenmeyer, buret, statif, tabung reaksi, rak tabung reaksi, spatula, alumunium foil, vorteks (Sunnymed Vortex Mixer), 
spektrofotometer (Thermo Scientific Genesys UV-Vis), mikropipet (Accumax), dan pipet ukur.

\section{Desain Penelitian}

Desain penelitian menggunakan satu faktor perlakuan yaitu kultur campuran Saccharomyces cerevisiae $2 \%$ dan Lactobacillus plantarum dengan konsentrasi sebesar $1 \%, 2 \%$, dan 4\%. Analisis data secara statistik menggunakan uji One Way Anova a 0.05 untuk sifat fisikokimia dilanjutkan dengan Duncan Multiple Range Test jika ada beda signifkan. Hasil penelitian sifat sensoris di analisis dengan Kruskal-Wallis $\alpha=0.05$.

\section{Tahapan Penelitian}

Penelitian ini diawali dengan melakukan pembuatan cuka belimbing wuluh yang meliputi fermentasi alkohol kemudian dilanjutkan dengan fermentasi asam asetat. Cuka kemudian dianalisis sifat fisikokimia (nilai $\mathrm{pH}$ wine dan $\mathrm{pH}$ cuka, kandungan alkohol wine, kandungan asam asetat, antioksidan, dan total fenolik) serta parameter sensoris meliputi warna, rasa, dan aroma.

\section{Metode}

Buah belimbing wuluh disortir kemudian dicuci bersih dan diekstrak. Ekstraksi dilakukan menggunakan blender dengan penambahan air, rasio belimbing wuluh dan air adalah 1:1 (b/v) kemudian dilakukan penyaringan. Ekstrak belimbing wuluh disterilisasi pada suhu $70{ }^{\circ} \mathrm{C}$ selama 30 menit kemudian diukur dan diatur $\mathrm{pH}$ menjadi 4 (jika belum tercapai maka ditambahkan natrium karbonat). Pengukuran gula reduksi yaitu 15 brix (jika belum tercapai maka ditambahkan gula pasir). Ekstrak belimbing wuluh diinokulasikan kultur campuran dengan formulasi sebagai berikut :

A : Saccharomyces cerevisiae $2 \%$ dan Lactobacillus plantarum $1 \%$

B : Saccharomyces cerevisiae $2 \%$ dan Lactobacillus plantarum $2 \%$

C : Saccharomyces cerevisiae $2 \%$ dan Lactobacillus plantarum $4 \%$

Kemudian dilakukan fermentasi alkohol selama 5 hari dengan suhu $37{ }^{\circ} \mathrm{C}$. Pengambilan supernatan dilakukan dengan sentrifugasi pada $4722 \mathrm{~g}$. Cairan ini disebut wine belimbing wuluh dan dilakukan analisis $\mathrm{pH}$ dan kadar alkohol wine. Proses fermentasi asam asetat dilakukan dengan inokulasi kultur Acetobacter acetii 4\% (v/v) kemudian diinkubasi selama 7 hari dengan suhu $37{ }^{\circ} \mathrm{C}$. Setelah fermentasi selesai, dilakukan pengambilan supernatan dengan sentrifugasi pada $7378 \mathrm{~g}$ kemudian dipasteurisasi dengan menggunakan waterbath suhu $70{ }^{\circ} \mathrm{C}$ dengan waktu 30 menit. Cuka belimbing wuluh kemudian dianalisis nilai pH wine dan $\mathrm{pH}$ cuka, kandungan alkohol wine, kandungan asam asetat, antioksidan, dan total fenolik) serta parameter sensoris meliputi warna, rasa, dan aroma.

\section{Prosedur Analisis}

\section{Analisis pH (Modifikasi SNI 06-698.11-2004)}

Kalibrasi pH meter dilakukan menggunakan buffer $\mathrm{pH} 4,7$, dan 10. $\mathrm{pH}$ meter dikeringkan menggunakan tisu selanjutnya elektroda dibilas dengan akuades. Elektroda dibilas menggunakan sampel kemudian dicelupkan ke dalam sampel sampai pH meter membaca pada skala yang tetap. Pembacaan skala atau angka yang tetap dicatat sebagai nilai pH sampel.

\section{Analisis Kadar Alkohol Wine (Modifikasi AOAC, 1995)}

Dua puluh lima mililiter wine belimbing wuluh ditambahkan $100 \mathrm{ml}$ akuades diletakkan dalam labu suling. Campuran disulingkan sehingga destilat tepat menjadi $25 \mathrm{ml}$. Piknometer yang telah diketahui beratnya kemudian diisi dengan destilat yang dihasilkan dan ditimbang pada suhu tertentu, misal $28{ }^{\circ} \mathrm{C}$. Berat destilat dapat dihitung dari berat pikno yang terdapat sampel dikurangi berat pikno kosong, misal berat destilat $=A$ gr Isi pikno 
dipindah diganti dengan akuades, pada suhu yang sama ditimbang sehingga diperoleh berat akuades, misal = B gr. Sehingga SG adalah :

Specific Gravity $=\frac{\mathrm{A}(\mathrm{gr})}{\mathrm{B}(\mathrm{gr})}=$ misal, 0.991

Kemudian cari suhunya dan konversikan kadar etanol menggunakan tabel konversi berat jenis kadar etanol $(\mathrm{v} / \mathrm{v})$.

\section{Analisis Kadar Asam Asetat (Sudarmadji dkk, 1997)}

Larutan cuka belimbing wuluh sebanyak $10 \mathrm{ml}$ diencerkan hingga $100 \mathrm{ml}$ kemudian ditempatkan ke dalam erlenmeyer. Sampel uji diambil $25 \mathrm{ml}$ dan ditempatkan pada erlenmeyer lain dan ditambahkan 2-3 tetes indicator phenolptalin (PP). Sampel kemudian dititrasi dengan $\mathrm{NaOH} 0.1 \mathrm{~N}$ terjadi perubahan warna menjadi merah muda. Rumus untuk menghitung total asam tertitrasi adalah :

$\%$ Total Asam $=\frac{\mathrm{ml} \mathrm{NaOH} \times \mathrm{N} \mathrm{NaOH} \times \mathrm{Grek}}{\text { Volume Bahan }(\mathrm{ml})}$

Keterangan :

Normalitas (N) $\mathrm{NaOH}=0.1 \mathrm{~N}$

Grek asam asetat $\quad=60$

\section{Analisis Aktivitas Antioksidan (Modifikasi Sompong et al, 2011)}

Pembuatan kurva standar vitamin C (konsentrasi 0, 25, 50, 75, 100, 125, dan 150 ppm) dilakukan terlebih dahulu untuk penentuan DPPH radical scavenging. Tahapan selanjutnya sebanyak $2 \mathrm{ml}$ larutan vitamin C tiap konsentrasi diambil dan ditambah $0.1 \mathrm{ml}$ DPPH konsentrasi $5 \mathrm{Mm}$. Campuran larutan vitamin $\mathrm{C}$ dan DPPH kemudian ditambahkan 4 $\mathrm{ml}$ methanol (PA) dan dicampur menggunakan vorteks hingga homogen. Campuran larutan kemudian didiamkan selama 60 menit dalam kondisi tertutup dan suhu ruang. Selanjutnya campuran larutan ditera absorbansinya dengan spektofotometer pada $\lambda=517 \mathrm{~nm}$. Nilai absorbansi digunakan untuk pembuatan kurva regresi linier DPPH radical scavenging oleh vitamin $\mathrm{C}$. Penentuan kadar DPPH radical scavenging sampel cuka belimbing wuluh dilakukan sesuai pembuatan kurva standar, tetapi mengganti $2 \mathrm{ml}$ larutan vitamin C menggunakan $2 \mathrm{ml}$ sampel cuka belimbing wuluh.

\section{Analisis Kadar Total Fenolik (Modifikasi Zhou et al, 2014)}

Penentuan kadar total fenolik menggunakan kurva standar gallic acid dan reagen Folin-Ciocalteau. Larutan standar gallic acid (konsentrasi 0, 10, 20, 30, 40, 50, dan 60 ppm) diambil $200 \mu \mathrm{l}$ masing-masing konsentrasi dan ditempatkan dalam tabung reakasi kemudian ditambahkan 1,5 $\mathrm{ml}$ reagen Folin-Ciocalteau (pengenceran 10x) dan dicampur dengan vorteks hingga homogen. Camputan asam galat dan reagen Folin-Ciocalteau ditambahkan $\mathrm{Na}_{2} \mathrm{CO}_{3}$ (dibuat dari $75 \mathrm{~g} / \mathrm{L}$ ) sebanyak $1,5 \mathrm{ml}$ dan dicampur hingga homogen. Campuran larutan diinkubasi selama 180 menit pada suhu kamar dan kondisi gelap. Nilai absorbansinya diukur dengan spektofotometer pada $\lambda=765 \mathrm{~nm}$. Kurva persamaan regresi linier dibuat dengan nilai absorbansi larutan standar asam galat. Pengujian kadar total fenol sampel dilakukan dengan cara yang sama dengan pembuatan kurva standar, yaitu dengan mengganti $200 \mu$ l larutan asam galat menjadi ekstrak sampel.

\section{Analisis Sifat Sensoris (Warna, Aroma, dan Rasa)}

Analisis sifat sensoris cuka yaitu uji hedonik untuk kesukaan panelis terhadap cuka belimbing wuluh dan uji mutu hedonik untuk mengetahui kesan panelis terhadap karakteristik sifat sensoris cuka belimbing wuluh yang meliputi warna, aroma, dan rasa. Analisis ini dilakukan dengan mengujikan sampel kepada panelis sebanyak 25 orang. Panelis diberikan kuesioner tertutup yang telah berisi pilihan skor jawaban. 
HASIL DAN PEMBAHASAN

Cuka dihasilkan melalui tahapan fermentasi alkohol dan fermentasi asam asetat. Hasil dari fermentasi alkohol adalah wine. Menurut Sanz et al (2014), wine memiliki pH yang berkisar antara 3-4. Kadar alkohol wine berdasarkan SNI adalah 5-15\% (v/v). Fermentasi asam asetat menghasilkan produk cuka. Secara umum cuka memiliki pH 2-3.5 (Chang et al, 2005) dan kadar asam asetat berdasarkan standar SNI adalah 4-12.5\%. Berikut merupakan hasil penelitian sifat fisikokimia cuka belimbing wuluh yang disajikan pada Tabel 1:

Tabel 1. Hasil Analisis Sifat Fisikokimia

\begin{tabular}{lccc}
\hline \multicolumn{1}{c}{ Parameter } & \multicolumn{3}{c}{ Penambahan L.plantarum } \\
\cline { 2 - 4 } & $\mathbf{1 \%}$ & $\mathbf{2 \%}$ & $\mathbf{4 \%}$ \\
\hline $\mathrm{pH}$ wine & 3.57 & 3.57 & 3.65 \\
$\mathrm{pH}$ cuka & 3.58 & 3.57 & 3.58 \\
Kadar alkohol wine (\%) & $5.68^{\mathrm{a}}$ & $9.46^{\mathrm{b}}$ & $7.88^{\mathrm{c}}$ \\
Kadar asam asetat (\%) & 0.34 & 0.35 & 0.32 \\
Aktivitas antioksidan (ppm) & 4.95 & 2.51 & 2.41 \\
Kadar senyawa fenolik (mg GAE/g) & 28.07 & 28.10 & 29.49 \\
\hline
\end{tabular}

Pemberian kode ${ }^{\mathrm{abc}}$ menunjukkan adanya perbedaan signifikan

\section{Nilai pH}

Nilai $\mathrm{pH}$ wine yang dihasilkan berkisar antara 3.57-3.65. Wine belimbing wuluh berasal dari jus belimbing wuluh yang telah dipasteurisasi dan disesuaikan kadar keasamannya dengan kondisi pertumbuhan optimum bakteri Saccharomyces cerevisiae dan Lactobacillus plantarum yaitu dengan nilai $\mathrm{pH}$ 4. Perubahan nilai $\mathrm{pH}$ dari 4 menjadi lebih asam yaitu 3.573.65 dapat disebabkan karena aktivitas bakteri, terutama Lactobacillus plantarum. Lactobacillus plantarum yang merupakan Bakteri Asam Laktat (BAL) memetabolisme gula dan menghasilkan asam organik terutama asam laktat. Asam laktat yang diproduksi akan terrdisosiasi menghasilkan $\mathrm{H}^{+}$dan $\mathrm{CH}_{3} \mathrm{CHOHCOO}$ selama proses fermentasi. Peningkatan asam laktat memungkinkan ion $\mathrm{H}+$ yang terbebaskan meningkat dan menyebabkan kadar keasaman semakin bertambah. Kadar keasaman yang meningkat menyebabkan penurunan pH produk (Primurdia dan Kusnadi, 2014 ; Purwandhani dkk, 2017 ; Walstra et al, 1999 dalam Hasan dkk, 2014).

Cuka yang dihasilkan berasal dari wine dengan $\mathrm{pH}$ awal 3.57-3.65. Nilai $\mathrm{pH}$ cuka yang dihasilkan setelah fermentasi antara 3.57-3.58. Cuka belimbing wuluh didapatkan melalui proses fermentasi asam asetat dengan kultur Acetobacter acetii proporsi $4 \%$. Asam asetat merupakan hasil metabolit utama dari Acetobacter acetii sehingga kadar asam asetat yang dihasilkan berkaitan erat dengan pH cuka. Priasty dkk (2013) melakukan penelitian terhadap hubungan kadar asam asetat dengan $\mathrm{pH}$ cuka kelapa dengan melakukan pemanenan cuka setiap minggu selama minggu pertama hingga minggu kedelapan. Hasil penelitian tersebut menunjukkan bahwa dari minggu pertama hingga minggu kedelapan $\mathrm{pH}$ cuka kelapa selalu mengalami kenaikan sedangkan kadar asam asetat cuka mengalami penurunan.

\section{Kadar Alkohol Wine}

Pertumbuhan terbaik khamir berada pada kondisi $\mathrm{pH} 4$ karena pada $\mathrm{pH}$ tersebut, khamir bekerja lebih cepat dalam memecah glukosa menjadi etanol (Riadi, 2007 ; Lohenapessy et al, 2017). Selain itu, interaksi antara khamir dan BAL juga memberikan keuntungan. Menurut Roostita \& Fleet (1996), khamir akan menyediakan banyak nutrien seperti asam amino, vitamin, dan garam asam piruvat yang dibutuhkan untuk produksi asam laktat dan menurut Loretan (1999) hasil metabolit dari BAL akan menyuplai sumber energi bagi khamir (Chen et al, 2017). Hal tersebut ditunjukkan dengan kadar alkohol pada proporsi $1 \%$ sebesar $5.68 \%$ kemudian mengalami peningkatan pada proporsi $2 \%$ menjadi $9.46 \%$. Namun pada proporsi $4 \%$, menurun menjadi $7.88 \%$. Hal tersebut dapat disebabkan karena proporsi bakteri yang terlalu banyak dalam suatu substrat. Li et al (2016) melaporkan bahwa nutrien atau zat gizi dalam suatu substrat tidak hanya dibutuhkan untuk pertumbuhan bakteri, 
namun juga dapat mempengaruhi hasil metabolit. Oleh karena itu komposisi nutrien dan konsentrasi bakteri dalam substrat menjadi faktor penting dalam proses fermentasi. Konsentrasi bakteri yang terlalu banyak akan menyebabkan pertumbuhan tidak optimal karena nutrien yang tersedia terbatas. Penelitian Chen et al (2016) yang melaporkan bahwa konsentrasi Lactobacillus plantarum kurang dari 4\% menghasilkan alkohol yang tinggi sedangkan pada saat konsentrasi Lactobacillus plantarum 6\%, pertumbuhan bakteri Saccharomyces cerevisiae terhambat sehingga produksi alkohol menurun.

\section{Kadar Asam Asetat}

Kadar asam asetat dalam suatu produk cuka dapat dipengaruhi oleh aktivitas bakteri Acetobacter acetii. Beberapa faktor yang mempengaruhi pertumbuhan Acetobacter acetii adalah nilai $\mathrm{pH}$ awal, suhu dan lama fermentasi, serta kadar alkohol dalam substrat. Du Toit \& Pretorius (2002) melaporkan bahwa sebagian besar bakteri asam asetat akan tumbuh dengan baik pada $\mathrm{pH}$ yang berkisar antara 5.4-6.3 dengan suhu optimal $25-30{ }^{\circ} \mathrm{C}$ (Bhat et al, 2014). Sedangkan pada penelitian ini pH dan suhu yang digunakan adalah 3.57-3.65 dan $37^{\circ} \mathrm{C}$. Selain itu, kadar alkohol yang terlalu tinggi akan menyebabkan kemampuan bakteri asam asetat menurun (Raspor \& Goranovic, 2008 dalam Bhat et al, 2014). Pada penelitian yang dilakukan oleh Hardoyo dkk (2007), kadar asam asetat paling tinggi ditemukan pada cuka yang difermentasi selama 11 hari dengan hasil asam asetat sebanyak $6 \%(\mathrm{v} / \mathrm{v})$. Sedangkan pada penelitian ini, lama fermentasi asam asetat dilakukan selama 7 hari. Kondisi optimum yang tidak terpenuhi tersebut menyebabkan aktivitas Acetobacter acetii tidak optimal sehingga kadar asam asetat yang dihasilkan sedikit yaitu $0.32-0.35 \%$. Sedangkan penelitian yang dilakukan oleh Kongkiattikajorn (2014) terhadap cuka rosella menghasilkan asam asetat sebesar $6.92 \%$. Penelitian serupa juga dilakukan oleh Spinosa et al (2015) terhadap cuka beras yang menunjukkan bahwa kadar asam asetat yang dihasilkan sebesar $7.1 \%$.

\section{Aktivitas Antioksidan dan Total Fenolik}

Aktivitas antioksidan yang dihasilkan pada konsentrasi $1 \%, 2 \%$, dan $4 \%$ secara berturut-turut yaitu $4.95 \mathrm{ppm}, 2.51 \mathrm{ppm}$, dan $2.41 \mathrm{ppm}$. Total fenolik yang dihasilkan secara berturut-turut pada konsentrasi 1\%, 2\%, dan 4\% yaitu $28.07 \mathrm{mg} \mathrm{GAE} / \mathrm{g}, 28.10 \mathrm{mg} \mathrm{GAE} / \mathrm{g}$ dan $29.49 \mathrm{mg} \mathrm{GAE} / \mathrm{g}$. Semakin banyak konsentrasi Lactobacillus plantarum yang diinokulasikan, maka semakin kuat aktivitas antioksidannya dan semakin meningkat kadar senyawa fenoliknya. Peningkatan senyawa fenolik pada umumnya diikuti dengan peningkatan aktivitas antioksidan dikarenakan gugus hidroksil yang lebih banyak yang dapat mencegah radikal bebas.

Menurut Zhang et al (2012), proses fermentasi dapat meningkatkan aktivitas antioksidan suatu produk yang berbahan dasar tanaman. Banyak perubahan biokimia yang terjadi selama fermentasi yang menyebabkan rasio antara komponen gizi dan anti-gizi berubah dan mempengaruhi karakteristik suatu produk secara bioaktivitas sehingga menjadi lebih mudah dicerna oleh tubuh. Konversi glikosida menjadi senyawa aglikon merupakan prinsip utama yang dapat meningkatkan nilai aktivitas antioksidan suatu produk makanan berbasis tanaman yang difermentasi (Hur et al, 2014).

Lactobacillus plantarum yang merupakan bakteri asam laktat merupakan mikroorganisme probiotik yang sangat penting dan dihubungkan dengan manfaatnya untuk kesehatan saluran pencernaan tubuh manusia. Ekstrak buah-buahan memiliki kandungan gula yang melimpah sehingga sangat sesuai menjadi media pertumbuhan bakteri probiotik asam laktat yang bermanfaat untuk meningkatkan manfaat kesehatan suatu produk seperti aktivitas antioksidan. Efek penangkal radikal bebas pada jus delima yang difermentasi menggunakan Lactobacillus plantarum mengalami peningkatan (Mousavi et al, 2013).

Buah belimbing wuluh secara alamiah kaya akan senyawa fenolik yang meliputi flavonoid, tanin, fenol, triterpenoid, dan saponin (Hasanuzzaman et al, 2013 ; Andayani dkk, 2014). Pada penelitian ini kadar senyawa fenolik meningkat seiring dengan proporsi bakteri Lactobacillus plantarum yang semakin tinggi. Hal ini merupakan suatu keuntungan yang 
dapat dihubungkan dengan kemampuan Lactobacillus plantarum dalam memproduksi lebih banyak fenol volatil dari asam fenolik (Couto et al, 2006 dalam Chen et al, 2017).

Selain itu, senyawa fenolik berhubungan erat dengan aktivitas antioksidan. Karakteristik antioksidan dari senyawa fenolik berasal dari kemampuan pelepasan proton, pembetukan kelat, dismutase radikal. Senyawa fenolik memberikan atom hidrogen dari gugus hidroksil ke senyawa radikal dan membentuk senyawa stabil fenoksil radikal. Sehingga penentuan total senyawa fenolik sangat penting untuk menentukan kemampuan antioksidan ekstrak tanaman (Aksoy et al, 2013).

\section{Warna, Aroma, dan Rasa}

Pengujian sifat sensoris aspek warna, aroma, dan rasa dilakukan dengan melibatkan panelis sebanyak 25 orang. Berikut merupakan hasil analisis sifat sensoris :

Tabel 2. Hasil Analisis Sifat Sensoris

\begin{tabular}{lccc}
\hline \multirow{2}{*}{ Parameter } & \multicolumn{3}{c}{ Penambahan L. plantarum } \\
\cline { 2 - 4 } & $\mathbf{1 \%}$ & $\mathbf{2 \%}$ & $\mathbf{4 \%}$ \\
\hline Warna & 3.36 & 3.32 & 3.28 \\
a. Hedonik & 3.56 & 3.36 & 3.44 \\
b. Mutu Hedonik & & & \\
Aroma & 2.32 & 2.04 & 2.24 \\
a. Hedonik & 2.40 & 2.24 & 2.32 \\
b. Mutu hedonik & & & \\
Rasa & 2.56 & 2.44 & 2.44 \\
a. Hedonik & 3.08 & 3.36 & 3.56 \\
b. Mutu Hedonik & &
\end{tabular}

Keterangan :

Nilai mutu hedonik (warna) $1=$ coklat muda; 2 = coklat kekuningan; $3=$ kuning kecoklatan; $4=$ kuning; $5=$ kuning kehijauan

Skor mutu hedonik (aroma) 1 = yeasty/ragi; 2 = sulfur alkoholik; 3 = alkoholik menyengat; 4 = fruity alkohol; $5=$ harum alkoholik

Skor mutu hedonik (rasa) 1 = pahit menyengat; 2 = pahit agak asam; 3 = asam agak pahit; 4 = sangat asam; 5 = asam agak manis

Hasil penelitian pada tabel di atas baik uji hedonik maupun uji mutu hedonik memiliki nilai yang berdekatan pada masing-masing proporsi $1 \%, 2 \%$ dan $4 \%$. Hasil uji Kruskal-Wallis menunjukkan tidak ada pengaruh signifikan pada keseluruhan sampel. Hasil uji hedonik warna pada ketiga sampel menghasilkan penilaian 'suka', sedangkan uji hedonik aroma dan rasa menghasilkan penilaian 'tidak suka' pada ketiga sampel. Pada uji mutu hedonik, panelis memberikan kesan 'kuning kecoklatan' pada aspek warna ketiga sampel, 'yeasty/ragi' pada aspek aroma ketiga sampel, dan 'asam agak pahit' pada aspek rasa untuk proporsi $1 \%$ dan $2 \%$, dan kesan 'sangat asam' untuk aspek rasa pada proporsi $4 \%$.

Menurut Tan (2005), warna dan aroma cuka sangat dipengaruhi oleh bahan baku pembuatannya. Bahan pembuatan cuka adalah buah belimbing wuluh yang memiliki warna hijau kekuningan. Perbedaan warna antara bahan baku dengan produk cuka yang telah jadi dapat disebabkan oleh proses pencoklatan atau browning. Browning disebabkan salah satunya karena adanya reaksi Mailard melibatkan asam amino yang bereaksi dengan gula melalui proses kondensasi dan rearrangement. Reaksi ini biasa terjadi pada buah-buahan dan sayuran, senyawa flavor, dan beberapa proses makanan (Zuhra, 2006).

Aroma ragi/yeasty pada produk cuka belimbing wuluh ini dapat dihubungkan dengan adanya etanol dan $\mathrm{CO}_{2}$ pada suatu produk. Seperti yang diketahui bahwa dalam suatu fermentasi, khamir bekerja dalam mengkonversi gula dan menghasilkan metabolit berupa alkohol dan karbondioksida. Sedangkan rasa cuka yang sangat asam dikarenakan kandungan utama dalam cuka adalah asam asetat. Selain asam asetat, cuka memiliki kandungan asam organik lainnya seperti asam sitrat, asam suksinat, asam format, dan asam laktat (Chen et al, 2017). 


\section{SIMPULAN}

Hasil penelitian yang telah dilakukan terdapat perbedaan signifikan pada kadar alkohol wine yang dihasilkan namun tidak pada sifat fisikokimia lainnya maupun sifat sensoris. Hasil dari pengujian diperoleh $\mathrm{pH}$ wine dan cuka adalah berkisar 3.57-3.65 dan masih sesuai dengan standar $\mathrm{pH}$ wine yaitu 3-4 dan $\mathrm{pH}$ cuka (2-3.5), maka $\mathrm{pH}$ wine dan cuka terbaik adalah 3.57, kadar alkohol tertinggi $9.46 \%$, kandungan asam asetat tertinggi $0.35 \%$ yang dihasilkan pada konsentrasi Lactobacillus plantarum 2\%. Aktivitas antioksidan tertinggi 4.95 ppm dan rasa sangat asam pada konsentrasi Lactobacillus plantarum 1\%. Penggunaan Lactobacillus plantarum $1 \%$ menghasilkan total fenolik tertinggi yaitu $29.49 \mathrm{mg} \mathrm{GAE} / \mathrm{g}$, dengan warna kuning kecoklatan, dan aroma yeasty/ragi. Berdasarkan hasil tersebut, maka perlakuan terbaik adalah cuka belimbing wuluh dengan konsentrasi Lactobacillus plantarum sebesar $2 \%$.

\section{DAFTAR PUSTAKA}

Aksoy, L., Kolay, E., Ağilönü, Y., Aslan, Z. and Kargioğlu, M. 2013. Free radical scavenging activity, total phenolic content, total antioxidant status, and total oxidant status of endemic Thermopsis turcica. Saudi Journal of Biological Sciences 20, 235-239.

Andayani, R., Chismirina, S., dan Kumalasari, I. 2014. Pengaruh ekstrak buah belimbing wuluh (Averrhoa bilimbi) terhadap interaksi Streptococcus sanguinis dan Streptococcus mutans secara in vitro. Cakradonya Dental Journal 6:2, 678-744.

AOAC. 1995. Official methods of analysis. Washington : Association of Official Analytical Chemists.

Bhat, S.V., Akhtar, R., and Amin, T. 2014. An overview on the biological production of vinegar. International Journal of Fermented Foods 3:2, 139-155.

Budak, N.H., Aykin, E., Seydim, A.C., Greene, A.K. and Guzel-Seydim, Z.B. 2014. Functional properties of vinegar. Journal of Food Science 79:5, 757-764.

Chang, R.C., Lee, H.C. and Ou, S.M. 2005. Investigation of the physicochemival properties of concentrated fruit vinegar. Journal of Food and Drug Analysis 13:4, 348-356.

Chen, H., Chen, T., Giudici, P., and Chen, F. 2016. Vinegar functions on health : constituents, sources, and formation mechanisms. Comprehensive a Reviews in Food Science and Food Safety 15, 1124-1138.

Chen, Y., Huang, Y., Bai, Y., Fu, C., Zhou, M., Gao, B., Wang, C., Li, D., Hu, Y. and Xu, N. 2017. Effects of mixed culture of Saccharomyces cerevisiae and Lactobacillus plantarum in alcoholic fermentation on the physicochemical and sensory properties of citrus vinegar. LWT-Food Science and Technology 84, 753-763.

Du Toit, W. J., and Pretorius, I. S. 2002. the occurrence, control and esoteric effect of acetic acid bacteria in winemaking. Annals of Microbiology 52:2, 155-179.

Firdausni. 2013. Pengaruh konsentrasi gula dan ragi dalam pembuatan cuka dari rosella (Hibiscus sabdariffa L.) terhadap mutu cuka rosella. Jurnal Litbang Industri 3:2, 77-83.

Hafzan, Y., Saw, J.W., and Fadzilah, I. 2017. Physicochemical properties, total phenolic content, and antioxidant capacity of homemade and commercial date (Phoenix Dactylifera L.) vinegar. International Food Research Journal 24:6, 2557-2562.

Hardoyo, Tjahjono, A.E, Primarini, D., Hartono dan Musa. 2007. Kondisi optimum fermentasi asam asetat menggunakan Acetobacter aceti B166. J. Sains MIPA 13:1, 17-20.

Harmanto, N. 2001. Jus Herbal Segar dan Menyehatkan. Jakarta : Elex Media Komputindo.

Hasan, A.E.Z., Artika, I.M., dan Abidin, S. 2014. Produksi asam laktat dan pola pertumbuhan bakteri asam laktat dengan pemberian dosis rendah propolis trigona spp asal pandeglang indonesia. Current Biochemistry 1:3, 126-135.

Hasanuzzaman, M., Ali, M.R., Hossain, M., Kuri, S. and Islam, M.S. 2013. Evaluation of total phenolic content, free radical scavenging activity and phytochemical screening of different extracts of Averrhoa bilimbi (fruits). International Current Pharmaceutical Journal 2:4, 92-96. 
Hur, S.J., Lee, S.Y., Kim, Y.C., Choi, I. and Kim, G.B. 2014. Effect of fermentation on the antioxidant activity in plant-based foods. Food Chemistry 160, 346-356.

Johnston, C.S. and Gaas, C.A. 2006. Vinegar : medicinal uses and antiglycemic effect. Medscape General Medicine 8:2, 61-69.

Kongkiattikajorn, J. 2014. Antioxidant properties of roselle vinegar production by mixed culture of Acetobacter aceti and Acetobacter cerevisiae. Kasetsart J. (Nat. Sci.) 48, $980-988$.

Li, C., Zhang, G.F., Mao, X., Wang, J.Y., Duan, C.Y., Wang, Z.J., and Liu, L.B. 2016. Growth and acid production of Lactobacillus delbrueckii ssp. bulgaricus ATCC 11842 in the fermentation of algal carcass. J. Dairy Sci 99, 4243-4250.

Liu, D., Zhu, Y., Beeftink, H. H., Ooijkaas, L. P., Rinzema, A., Chen, J. and Tramper, J. 2004. Chinese vinegar and it's solid-state fermentation process. Food Reviews International 20:4, 407-424.

Lohenapessy, S., Gunam, I.B.W., dan Arnata, I.W. 2017. Pengaruh berbagai merek dried yeast (Saccharomyces sp.) dan $\mathrm{pH}$ awal fermentasi terhadap karakteristik wine salak bali. Jurnal Teknologi Industri \& Hasil Pertanian 22:2, 63-72.

Loretan, T. 1999. The diversity and technological properties of yeasts from indigenous traditional south african fermented milks. Thesis. University Orange Free State. Bloemfontein, South Africa.

Masruhen. 2010. Pengaruh pemberian infus buah belimbing wuluh (Averrhoa bilimbi I.) Terhadap kadar kolesterol darah tikus. Jurnal Farmasains 1:1, 1-5.

Mousavi, Z.E., Mousavi, S.M., Razavi, S.H. and Hadinejad, M. 2013. Effect of fermentation of pomegranate juice by Lactobacillus plantarum and Lactobacillus acidophilus on the antioxidant activity and metabolism of sugars, organic acids, and phenolic compounds. Food Biotechnology 27:1, 1-13.

Ni'maturrohmah, W. 2014. pemanfaatan limbah kulit buah pisang kepok (Musa paradisiaca) sebagai bahan dasar pembuatan cuka organik dengan penambahan Acetobacter aceti dengan konsentrasi yang berbeda. Skripsi. Universitas Muhammadiyah Surakarta. Surakarta.

Oktaviana, Y.R. 2012. Kombinasi konsentrasi maltodekstrin dan suhu pemanasan terhadap kualitas minuman serbuk belimbing wuluh (Averrhoa Bilimbi Linn.). Skripsi. Universitas Atma Jaya. Yogyakarta.

Priasty, E.W., Hasanuddin, dan Dewi, K.H. 2013. Kualitas asam cuka kelapa (Cocos nucifera L.) dengan metode lambat (slow methods). Jurnal Argo Industri 3:1, 1-13.

Primurdia, E.G. dan Kusnadi, J. aktivitas antioksidan minuman probiotik sari kurma (Phoenix dactilyfera I.) dengan isolat L. plantarum dan L. casei. Jurnal Pangan dan Agroindustri 2:3, 98-109.

Purwandhani, S.N., Utami, T., Millati, R. dan Rahayu, E.S. 2017. Potensi Lactobacillus plantarum yang diisolasi dari dadih dalam meningkatkan kadar folat susu fermentasi. AGRITECH 37:4, 395-401.

Riadi, Lieke. 2007. Teknologi Fermentasi. Yogyakarta : Graha Ilmu.

Roostita, R., and Fleet, G. H. 1996. The occurence and growth of yeasts in camembert and blue-veined cheeses. International Journal of Food Microbiology 28:3, 393-404.

Sanz, M.D.T. Cediel, I.M, Lobon, J.M.P., Mata, M.G., Rodriguez, M.L.P., Cuenca, A.R., Suarez, M.J.V and Revilla, M.A.Z. 2014. Wine and its Analiysis. Facultad de Farmacia Universidad Complutense de Madrid.

Sompong, R., Siebenhandl-Ehn, S., Linsberger-Martin, G. and Berghofer, E. 2011. Physicochemical and antioxidative properties of red and black rice varieties from Thailand, China, and Sri Lanka. J. Food Chem. 124:2011, 132-140.

Spinosa, W.A., Junior, V.D., Galvan, D., Fiorio, J.L. and Gomez, R.J.H.C. 2015. Vinegar rice (Oryza sativa L.) poduced by submerged fermentation process from alcoholic fermented rice. Food Science and Technology, 35:1, 196-201.

Standar Nasional Indonesia. 2004. Air dan Air Limbah - Bagian 11 : Cara Uji Derajat Keasaman $(\mathrm{pH})$ dengan Menggunakan Alat $\mathrm{pH}$ meter. Badan Standardisasi Nasional. 
Sudarmadji, S., Haryono, B. dan Suhardi. 1997. Analisis Bahan Makanan dan Pertanian. Liberty. Yogyakarta.

Tan, San Chiang. 2005. Vinegar Fermentation. Thesis. Lousiana State University, La Fayette.

Wang, Z., Yan, M., Chen, X., Li, D., Qin, L., Li, Z., Yao, J. and Liang, X. 2013. Mixed culture of Saccharomyces cerevisiae and Acetobacter pasteurianus for acetic acid production. Biochemical Enginering Journal 79, 41-45.

Zhang, Z., Soccol, C., and Pandey, A. 2012. Production of powerful antioxidants supplements via solid-state fermentation of wheat (Triticum aestivum Linn.). Food Technology and Biotechnology 50:1, 32-39.

Zhou, Z., Chen, X., Zhang, M. and Blanchard, C. 2014. Phenolics, flavonoids, proanthocyanidin and antioxidant activity of brown rice with different pericarp colors following storage. Journal of Stored Products Research 59, 120-125.

Zuhra, C.F. 2006. Flavor (Citarasa). Medan : Universitas Sumatera Utara. 